\title{
ANALYSIS OF ZAKAT MANAGEMENT IN BRUNEI DARUSSALAM
}

\author{
MOHAMED SHARIF BASHIR \\ NURUL NABILAH HAJI ALI \\ Faculty of Business and Management Sciences \\ Sultan Sharif Ali Islamic \\ University, Brunei Darussalam
}

\begin{abstract}
The main objective of this paper is to analyze the management of zakat funds in Brunei Darussalam. More specifically, it aims at investigating how zakat funds recipients perceive the quality of the current zakat management with special attention to the aspect of zakat funds disbursement. It also aims to examine how efficient Brunei's zakat administration is, particularly the distribution aspect. This paper is explanatory and descriptive in nature and uses both secondary and primary data to examine the trends of zakat collection and distribution. The findings in this paper show that zakat management in Brunei Darussalam is progressing to achieve the main objectives of zakat system. The paper also provides some useful policy implications to improve the management of zakat funds and how policy-makers can respond to the challenges positively as well as to develop and support zakat institutions in Brunei Darussalam to be more efficient and reliable in the collection and distribution of zakat funds.
\end{abstract}

Keyword: Zakat management, Islamic finance, zakat recipients, Brunei Darussalam.

\section{Introduction}

Zakat is one of the five pillars of Islam, having important socioeconomic implications, and has to be administered by the state. Zakat is a yearly premium on all forms of accumulated productive wealth as well as a variety of agricultural products, calculated at various rates according to the nature of the wealth or product to be paid to the needy individuals of the Muslim community for their rehabilitation. The Islamic renaissance in the present world has led to its institutionalized administration in some Muslim countries, such as Brunei, Malaysia, Sudan, Saudi Arabia, and Kuwait (Kahf, 1997; Sadeq, 1994). 
Zakat is an obligatory religious duty on Muslims to achieve divinely prescribed socioeconomic objectives. It is a self-help measure adopted with full religious backing to support those poor and destitute who are unable to help themselves to alleviate misery and poverty in Muslim society (Chapra, 1992). Muslims in different countries, realizing the pivotal role of the zakat system, embarked on ways to resuscitate the zakat institution. Two systems of zakat management commonly exist in the Muslim world: compulsory and voluntary systems. Compulsory zakat system is mostly managed by governments, while voluntary zakat system has multiple models. The common models are the neighborhood or committee-based model, nongovernmental organization-based model, semi-government-based model, and government-based model (Abioye, 2008).

The management of zakat in Brunei Darussalam is governed by the Islamic Religious Council of Brunei Darussalam (MUIB) under the Ministry of Religious Affairs (MORA). MUIB is given the authority by the laws of Brunei to collect and distribute the zakat funds ${ }^{1}$. This role conforms to Islamic law in obligating the state to exercise zakat as a vital instrument to fulfill basic needs in Muslim society as well as an instrument of fiscal policy. MUIB has provided social security for the poor and the needy in society throughout the last two decades (Abdullah, 2010a).

Brunei Darussalam is a small and oil-rich country. It is located on the northern coast of Borneo Island, surrounded by the two eastern provinces of Malaysia and the South China Sea on the north. Brunei's population is approaching 400,000 . Around $70 \%$ of the population is Muslim. Brunei is a constitutional sultanate, and the sultan wields broad powers under a state of emergency that has been in effect since 1962. It runs under the political philosophy of the Malay Islamic Monarchy. Brunei's economy is heavily reliant upon exporting crude oil and natural gas. Revenues from these sectors account for half of GDP, around $90 \%$ of exports, and $80 \%$ of government revenue. Therefore, Brunei is the fourth-largest oil producer in Southeast Asia, averaging about 175,000 barrels a day. It also is the ninth-largest exporter of liquefied natural gas in the world. Much of the country's wealth is controlled by the strong central government. The Brunei Investment Authority General Reserve Fund has an estimated USD30 billion in assets (Oxford Business Group, 2011). 


\section{Regulations and the Act of Zakat in Brunei}

Several steps have been implemented to improve the management of zakat in Brunei Darussalam since the establishment of Baitul Mal as a governmental unit responsible for zakat collection and distribution. However, after $1^{\text {st }}$ November 1999, the name of Baitul Mal was changed to the Department of Zakat Collection and Distribution (DZCD) with approval from a monthly ministerial meeting (MBK - 9/1999, held on $19^{\text {th }}$ October 1999). The department is divided into many sections, one of them called the Section of Collection and Distribution. This section is divided into five units: a unit of administration and distribution of zakat, unit of collection, unit of application/investigation/observation, unit of secretariat meeting, and unit of housing.

Offices of the zakat collection and distribution department operate in all four districts of Brunei. In addition, the department is responsible for the overall activities of the collection and distribution of zakat funds and is also accountable not only in the matter of zakat but some other tasks such as registration for Mualaf and activities of Baitul Mal and Waqaf (Islamic Religious Council of Brunei, 2010).

The main objectives of the zakat system can be explained as follows:

(1) It is an act of purifying of one's soul, enabling one to come closer to Allah (SWT). As an act to protect the poor and needy from any financial and material problems, it benefits not only the poor but also the rich because their assistance will be rewarded by Allah (SWT) in the hereafter for their act of obedience to Allah (SWT).

(2) It plays an important role in the progress of the spiritual aspect, the economy, and technology in society.

(3) Zakat functions as a means of eradicating poverty in society, and it also simultaneously motivates individuals in becoming responsible and caring people. It ensures ideal and sustainable social security for the poor, needy, old, disabled, and other unfortunate individuals in society.

(4) The Islamic institution of zakat creates creative individuals who are non-materialistic, self-sufficient, and always grateful for the bounties of Allah (SWT).

The main objective of this paper is to analyze zakat management in Brunei Darussalam and how zakat recipients perceive the quality of the current zakat management, especially in relation to disbursement. 
It also examines zakat disbursement's effects on the recipients' social and financial status. This paper may shed some light on the possible responses that address the main issues, including the distribution and investment of zakat funds.

The rest of the paper is organized as follows. Section 2 provides a brief perspective on fundamentals of zakat in Islam, while section 3 describes the data and method. Section 4 presents results and discussion. Section 5 offers some policy implications followed by a conclusion in section 6 .

\section{Fundamentals of Zakat in Islam}

\section{Main Objective of the Zakat System}

In the early Islamic period, the institution of zakat was strong, and the poor and the needy were helped through this institution. The Holy Prophet $(P B U H)$ had predicted that there would be such an abundance of wealth in the Muslim community that the class of persons who deserve zakat and charity would be entirely eliminated. This prediction came true. The Muslims had so much wealth that there was none to deserve zakat. However, this happened at a time when Muslims had an honest government, a just ruler, and the right system. Unlike other economic systems, from its inception, Islam had to find a reliable solution to all sorts of social problems, including poverty and social injustice. To achieve this objective, Islam's main emphasis is to guarantee the steady provision of basic human needs (food, shelter, clothing, and other prerequisites) at levels that seem to be sufficient to preserve human dignity, achieving the objectives of socioeconomic development on the basis that poverty and hunger are the key to atheism (al-Hashimi, 2007; Awad, 1998).

Based on need and time factors, Islam differentiates between two types of needy groups: the poor, Fakir, and the destitute, Miskin. The former is defined as any person who, using his own resources, cannot maintain himself at the sufficiency level for a period of one year. The latter refers to those who are unable to secure their needs (in terms of food) for one day. Such a difference yields a very wide range of people who could be classified as poor. Both types are entitled to zakat.

Poverty in Islam is not a matter of the inability to satisfy basic needs for human survival at a point in time, as some scholars allege; rather, it 
is a matter of the inability to satisfy these needs through a sustainable process for a long period of time, almost a year. Thus, sustainability in meeting basic human needs is a key element and point of departure to distinguish the poor from the non-poor (Abdullah, 2010a). Islam views poverty as a social problem that must be eradicated. This is clearly envisioned in almost all of the Qur'an verses related to poverty and the poor (Al-Qaradawi, 1997; Sahl, 1997). From the Islamic perspective, assisting the poor is not considered solely charity; rather, it is an act of justice. This is because the poor are entitled to a share of the rich's wealth by virtue of being co-owners of the natural resources from which their wealth is derived. The Qur'an cited that severe chastisement will be inflicted on those rich who do not help the poor and worse will be the fate of those rich who acquire money from the helpless, the poor, and the orphaned through illegal means. Thus, zakat has been imposed on wealth and income as a legitimate right of the poor to the wealth of the rich (Chaudry, 1999). In this respect, the Islamic economic system neither negates the legitimacy of acquiring wealth as communism does, nor seeks to help the poor through the organization of mutual support schemes as socialism does. It merely retrieves for the poor their appropriate share of the wealth acquired by the rich. Transfers from the rich to the poor could be conceived as a mechanism by which poverty can be eradicated and a minimum standard of living can be attained by every member of society. Islam attributes the prevalence of poverty to man's deviation from divine religion and to corruption in the economic system. This view contrasts with that of capitalism, where both poverty and wealth are regarded as a direct product of human efforts, so the poor are responsible for the creation of their own poverty (Hassan, 2010; Sadeq, 1994; Zayas, 2003).

\section{Addressing the Poverty Problem}

Furthermore, from the Islamic economic perspective, the consequences are many, and a few can be cited as follows:

(1) Poverty has a direct consequence on human faith in God where wealth and resources tend to be concentrated in a few hands while the many suffer from deprivation. Unless wealth and resources are equally distributed among people, poverty will lead eventually to atheism. Thus, deviation from divine religion originates from poverty that results from the misdistribution of wealth and resources. 
(2) Poverty also has a direct effect on human ethics and behavior, tending to force those who fall into deprivation and destitution to engage in unlawful behavior such as robbery. Deprivation may also lead to suspicion of ethical and religious values.

(3) Poverty may endanger human thought. In other words, the poor, who are unable to meet their basic needs, cannot think well.

(4) Poverty may have a direct impact on family structure, persistence, and cohesion. Within the family structure, poverty can be regarded as a main obstacle in a marriage. Poverty may also lead to the destruction of family ties, e.g., through divorce. Poverty may endanger the social fabric and social security and stability.

The spread of poverty in Muslim nations will threaten their unity, integrity, freedom, and sovereignty because the poor and destitute will have no enthusiasm to defend their country if wealth and resources are not distributed equally among all the citizens. To correct this situation and to narrow the growing income gap between the rich and the poor, zakat has been used as an ideal eradication mechanism. This objective could be achieved by redistributing income in favor of the poor as well as by utilizing it in the employment of idle manpower through either lending or direct investment. The poor and destitute are the first two of the eight categories designated in Islam as eligible for zakat funds (Hassan, 2010).

There are eight categories or groups of beneficiaries who qualify to receive zakat. In other words, zakat can be distributed only to people in any of the eight eligible categories indicated in the Qur'an. These eight types of eligible beneficiaries comprise what are known as Asnaf, which are ranked according to their eligibility as follows: the poor, the destitute, zakat collectors or those employed to administer the funds, the appeased (non-Muslim inclined to enter or has already converted to Islam), slaves (captives), debtors, those in the cause of God, and the wayfarers or travelers who are stranded in a foreign land (Surat at-Tawbah: Chapter 9; Verse 60). The first two categories are the needy, while the remaining six are not necessarily poor but are still entitled to zakat. The distribution of zakat funds should be based on the needs of all the groups. In some cases, the transfer of allocated zakat funds from one category to another can be allowed according to priorities and the degree of vulnerability. This reflects the flexibility of the zakat system regarding its predetermined Asnaf. Zakat cannot be regarded as a distribution mechanism alone, as some scholars argue; 
it also has an income-generating and, hence, a development rationale. This is mainly the economic wisdom behind the zakat: to prohibit and thus mobilize hoarding, leading in turn to more investment and further income generation and development. The poor are given not only what satisfies their basic needs but also capital to produce and earn income (Kahf, 1990; Sahl, 1997).

The obligatory nature of annual zakat payments and the aforementioned definition of the poor are of particular economic significance as follows:

(1) It means that the poor are entitled to be given a certain proportion of aggregate income and wealth every year.

(2) This proportion is assumed to be sufficient to meet the poor's requirements for a year.

(3) Under investment opportunities, if the poor are enlightened as to how to invest their zakat proceeds, they may in the following year no longer be in poverty.

(4) It follows from the third that, if a poor person invests successfully, he may turn into a zakat payer rather than a recipient.

(5) Being a zakat payer means a reduction in the number of the poor by some proportion, opening opportunity for new poor people to participate in the process.

The poverty-alleviation effects of zakat are reinforced in an Islamic economy by a number of poverty-preventing measures. Chief among these measures is that all natural resources are deemed collectively owned by all members of the communities that control and utilize them; the prohibition of monopolies and restrictive practices is another effective poverty-preventing measure through which poverty is combated in an Islamic economy. Being the chief instrument through which the rich exploited the poor, usury was regarded as a chief economic evil that was prohibited and replaced by a host of financial arrangements that benefit both the funder and the funded. These include Musharakah (profit- and loss-sharing); Murabahah (forward sale) or Ijar-Tamlik, (renting of goods); and Gard Hassan (forward purchase or free loans) (Billah, 2007).

Islam specifies the state's responsibility and commitment toward its nationals, including vulnerable groups such as the poor, widows, the disabled, the aged, etc. Every needy person has the right to ask the state to provide him with food, shelter, clothing, etc. However, the 
level at which these items are to be provided is sufficiency rather than subsistence, which is emphasized by most prevailing measures of poverty. The modern approach to the zakat institution is a significant economic and social instrument for poverty alleviation and the stability of the Muslim world (Hassan, 2010; Sahl, 1997).

\section{Methodology and Data Sources}

This paper is explanatory and descriptive in nature and uses both secondary and primary data to examine the trends of zakat collection and distribution. The research has obtained primary data on zakat through survey questionnaires distributed to zakat recipients based on a sample size of 50. With this small sample size, the present paper can still contribute significantly to the existing zakat studies, at least at an exploratory level. Non-probability convenience sampling has been used to collect data from zakat fund recipients in Bandar Seri Begawan, the capital city of Brunei Darussalam. The questionnaire forms were distributed in May 2011. The purpose of the questionnaire is to look at the perspective of the zakat recipients. The questionnaire consists of five sets of questions, including the respondents' demographic characteristics, view on the early stage of applying for zakat, view after receiving zakat funds, view on the Empowerment Zakat Recipients Program (EZRP), and view on the objective of zakat distribution. A five-point Likert scale ranging from "strongly agree" to "strongly disagree" was used to measure 10 items of the respondents' feedback after receiving zakat funds. A reliability test was performed and showed that Cronbach's alpha was 0.80, which indicates a sufficient level of reliability. The secondary data was obtained from MUIB statistics on zakat collection and distribution from 2001 to 2009.

All figures in this paper are in current Brunei Darussalam dollar (BND\$) including data on zakat funds ${ }^{2}$. The sources of zakat funds as practiced in Brunei are divided into two types: Zakat Fitrah and Zakat on wealth. The detailed information for each is as follows:

\section{Zakat Fitrah}

Zakat Fitrah is also known as zakat on the person, zakat of Ramadan, or Zakat Fitrah. Zakat Fitrah was obliged in the second year of the Islamic Calendar (Hijrah), the same year that fasting in Ramadan was made obligatory. Zakat Fitrah is prescribed as a means of purification for the person who fasts, redressing wrong deeds and undesirable words uttered during fasting. It also serves as aid to the needy. 
(b)

\section{Zakat on Wealth}

There are six types zakat for wealth: zakat for income and salary, zakat for business, zakat for savings, zakat for stocks, zakat for gold and silver, which includes currencies and bank-notes, and zakat for agriculture and poultry (Islamic Religious Council of Brunei, 2010).

\section{Results and Discussion}

\section{Respondents' Demographic Characteristics and Views}

As shown in Table 1, the highest percentage for gender is female, accounting for $74 \%$ of the respondents, while males accounted for $26 \%$. In regard to age, the highest age group is $40-49$ years old, accounting for $30 \%$ of the respondents, followed by those between the age of 30 and 39 and those who are over 50 years old with a percentage of $26 \%$, while the age group of 20-29 years accounted for $18 \%$. The majority of the respondents' age is between 30 and 49 years old. Almost all of the respondents are from the Malay ethnic group, accounting for $92 \%$, followed by Chinese at $6 \%$, and others (the Iban ethnic group) at $2 \%$. This indicates that the respondents are dominated by Malay. The highest percentage for education level have a secondary school education at $54 \%$, followed by those with no education, including those with an education level at primary 3 and below accounting for $36 \%$ and those with a primary education level at $10 \%$. In regard to employment, the highest percentage, $74 \%$ of the respondents, are unemployed, followed by those who work in the private sector at $18 \%$. The remaining $8 \%$ work in the government sector. This indicates the highest percentage of respondents is unemployed. A majority of the respondents are married $(54 \%)$, followed by $26 \%$ who are divorced, while the remaining $20 \%$ are widowed. Hence, the results show that the highest percentage of the respondents is married.

In regard to family size, the highest percentage of respondents has three to five dependents (50\%), followed by those with one to two dependents (32\%). Around 10\% of the respondents have six to seven dependents, and $8 \%$ have more than seven dependents. This shows that the majority of the respondents have between one and five children. 
IJMS 19 (2), 75-102 (2012)

Table 1

Respondents' Demographic Characteristics

\begin{tabular}{|c|c|c|c|}
\hline \multicolumn{2}{|l|}{ Characteristics } & \multirow{2}{*}{$\frac{\text { Frequency }}{13}$} & \multirow{2}{*}{$\frac{\text { Percentage }(\%)}{26}$} \\
\hline Gender & Male & & \\
\hline & Female & 37 & 74 \\
\hline \multirow[t]{4}{*}{ Age } & $20-29$ & 9 & 18 \\
\hline & $30-39$ & 13 & 26 \\
\hline & $40-49$ & 15 & 30 \\
\hline & $50>$ & 13 & 26 \\
\hline \multirow[t]{3}{*}{ Race } & Malay & 46 & 92 \\
\hline & Chinese & 3 & 6 \\
\hline & Other & 1 & 2 \\
\hline \multirow[t]{3}{*}{ Education } & Primary & 5 & 10 \\
\hline & Secondary & 27 & 54 \\
\hline & No education & 18 & 36 \\
\hline \multirow[t]{3}{*}{ Employment } & Government & 4 & 8 \\
\hline & Private & 9 & 18 \\
\hline & Unemployed & 37 & 74 \\
\hline \multirow[t]{3}{*}{ Marital Status } & Married & 27 & 54 \\
\hline & Divorced & 13 & 26 \\
\hline & Widowed & 10 & 20 \\
\hline \multirow[t]{4}{*}{ Family Size } & $1-2$ & 16 & 32 \\
\hline & $3-5$ & 25 & 50 \\
\hline & $6-7$ & 5 & 10 \\
\hline & $>7$ & 4 & 8 \\
\hline
\end{tabular}

In regard to the respondents' view on the application process, as shown in Table 2, in six categories (Asnaf) of those are eligible to receive zakat, the highest percentage is from Fakir and Miskin (78\%), followed by Gharimin (14\%). The remaining are from Muallaf (8\%). These results indicate that the highest frequency occurs for Fakir and Miskin. A majority of the respondents, $52 \%$, said that it took about four to 12 months for their application to be answered, followed by $36 \%$ who indicated more than a year, and the remaining $12 \%$ said it took about one to three months. This indicated that a majority of the respondents waited about four months or more for their applications to be accepted. 
IJMS 19 (2), 75-102 (2012)

Table 2

Respondents' View on the Application Process

\begin{tabular}{ccc}
\hline & Frequency & Percentage $(\%)$ \\
\hline Zakat categories & 39 & 78 \\
Fakir/Miskin & 4 & 8 \\
Muallaf & 7 & 14 \\
Gharimin & 6 & \\
\hline Duration of response & 6 & 12 \\
1-3months & 26 & 52 \\
4-12months & 18 & 36 \\
\hline 1 year & &
\end{tabular}

In regard to the type of assistance received by the respondents, basic needs accounted for $36 \%$ of the recipients, followed by education at $24 \%$, emergency at $20 \%$, Gharimin at $12 \%$, and the remaining $8 \%$ from Muallaf. This indicates that the highest frequency occurs for spending on basic needs such as food, clothing, housing needs, showing the importance of zakat in meeting these needs. As shown in Table 3, around $46 \%$ of the recipients said that their monthly expenses are between $\mathrm{BND} \$ 300$ and $\mathrm{BND} \$ 499$, followed by $30 \%$ of the respondents who said that their monthly expenses are from BND $\$ 500$ to BND $\$ 1000$. The remaining $24 \%$ of the respondents spend $B N D \$ 100$ to $B N D \$ 299$ for monthly expenses. These results show that the majority of the respondents are spending about BND $\$ 300$ to BND $\$ 499$ monthly. A majority of the recipients, $66 \%$, responded that the zakat funds they receive are enough to meet their monthly expenditures. However, $34 \%$ of the recipients said that the zakat funds received are insufficient to cover their expenses. This illustrates that the highest percentage of respondents agree that the zakat funds are sufficient to cover their monthly expenses. Around $34 \%$ of the respondents confirmed that the zakat funds are insufficient to cover their monthly expenses. A majority of the respondents (82\%) said that they need around BND $\$ 300$ to $B N D \$ 800$ to pay their monthly expenses. The remaining $18 \%$ of the respondents need around BND $\$ 1000$. These results confirm that the amount of funding needed is not less than BND $\$ 500$ to cover the recipients' monthly expenses. 
IJMS 19 (2), 75-102 (2012)

Table 3

Respondents' View after Receiving Zakat Funds

\begin{tabular}{ccc}
\hline & Frequency & Percentage (\%) \\
\hline Types of funds received & 12 & 24 \\
Education & 10 & 20 \\
Emergency & 4 & 8 \\
Muallaf & 6 & 12 \\
Gharimin & 18 & 36 \\
Basic needs & & \\
100-299 & 12 & 24 \\
$300-499$ & 23 & 46 \\
$500-1000$ & 15 & 30 \\
\hline Monthly expenses (BND) & & 66 \\
Yes & 33 & 34 \\
No & 17 & 10 \\
\hline Zakat sufficiency & & 12 \\
Noeded expenses (BND\$) & 5 & 32 \\
400 & 6 & 16 \\
500 & 16 & 12 \\
600 & 8 & 18 \\
800 & 6 & \\
1000 & 9 & \\
\hline & & \\
\hline
\end{tabular}

Table 4 shows that, due to lack of awareness of the Empowerment Zakat Recipients Program (EZRP), the absolute majority did not join this program and obviously had not heard about it. Only around 6\% of the respondents joined EZRP, while the majority of the respondents joined the program within one year.

Table 4

Respondents' View on Empowerment Zakat Recipients Program

\begin{tabular}{lccc}
\hline & Frequency & Percentage (\%) \\
\hline Recipients that joined EZRP & 3 & 6 \\
& Yes & 47 & 94 \\
\hline No & & \\
\hline Period of time & & 3 & 6 \\
& $<1$ Year & 47 & 94 \\
\hline
\end{tabular}


In regard to the respondents' feedback after receiving zakat funds, as shown in Table 5, $64 \%$ of the respondents agreed that the process of applying for zakat is short and simple, $12 \%$ of the 50 respondents disagreed, $10 \%$ strongly agreed, $8 \%$ strongly disagreed, and $6 \%$ said that they neither agreed nor disagreed. This shows that the majority of the respondents agreed that the process of applying for zakat is short and simple. Table 5 also shows that the highest percentage, $44 \%$, agreed that zakat funds help to improve their children's education level. The second-highest percentage, 30\%, strongly agreed, the thirdhighest percentage, $16 \%$, disagreed, and $10 \%$ neither agreed nor disagreed. These results show that the majority of the respondents agreed that zakat helps to improve their children's education level. $68 \%$ agreed that zakat funds help them to acquire their basic necessities, $22 \%$ agreed, $6 \%$ neither agreed nor disagreed, and the remaining $4 \%$ said that they disagreed that zakat funds help them to meet their basic needs. They said that nothing has improved since they began receiving help from zakat funds.

Around $66 \%$ of the respondents strongly agreed and $14 \%$ of them agreed that zakat funds assist them in paying their debts, whereas $14 \%$ said it does not help them to pay their debts, and $6 \%$ said that they neither agreed nor disagreed. Table 5 shows that the highest percentage of the respondents agreed that zakat funds help them to pay their debts. $60 \%$ agreed and $24 \%$ strongly agreed that their standard of living improved after they received zakat funds. On the other hand, $10 \%$ disagreed, and $6 \%$ neither agreed nor disagreed. This shows that the highest percentage of respondents agreed that zakat funds help to improve their standard of living. The results show that the highest percentage, $36 \%$ of the respondents, agreed that zakat funds contribute money to build their homes. The second-highest percentage of the respondents, $30 \%$, disagreed, followed by $20 \%$ who neither agreed nor disagreed, and $4 \%$ represented those who strongly disagreed. This proves that the majority of the respondents agreed that the zakat funds contribute money to build their homes.

Virtually $62 \%$ of the respondents agreed and $20 \%$ strongly agreed that zakat funds help to ease their burden. On the other hand, $8 \%$ neither agreed nor disagreed, $6 \%$ disagreed, and $4 \%$ strongly disagreed. This indicates that the majority of the respondents agreed that zakat funds help to ease their burden. Nearly $72 \%$ of the respondents agreed and $16 \%$ strongly agreed that their income increased after receiving zakat funds. However, 10\% disagreed, and 2\% neither agreed nor disagreed. This indicates that the majority of the respondents agreed 
that their income increased after receiving zakat funds. Almost $72 \%$ of the respondents agreed and $16 \%$ strongly agreed that their income increased after receiving zakat funds. However, $10 \%$ of the respondents disagreed, and $2 \%$ neither agreed nor disagreed.

Nearly $76 \%$ of the respondents agreed and $18 \%$ strongly agreed that life became easier with the help of zakat. On the other hand, $4 \%$ disagreed, and $6 \%$ neither agreed nor disagreed. This indicates that the majority of the respondents agreed that life became easier with the help of zakat. About 32\% of the respondents disagreed that zakat funds help to pay for their family members' medical expenses, $28 \%$ agreed, 22\% neither agreed nor disagreed, and the remaining $18 \%$ said that they strongly agreed that zakat funds help to pay for their family members' medical expenses. This shows that the majority of the respondents disagreed that zakat funds help to pay for medical expenses. The reason is that the recipients usually go to government hospitals or clinics if they do not feel well, and the cost is only one dollar, so it does not matter whether zakat helps or not because they still manage to pay for medical expenses.

Table 5

Respondents' Feedback after Receiving Zakat Fund (\%)

\begin{tabular}{lccccc}
\hline Statements & SA & A & NT & DA & SDA \\
\hline Application process for zakat fund is short and simple & 10 & 64 & 6 & 12 & 8 \\
It helps to improve children education & 30 & 44 & 0 & 10 & 16 \\
It helps to meet basic needs & 11 & 34 & 3 & 2 & 0 \\
It helps to pay debts & 7 & 33 & 3 & 7 & 0 \\
It helps to improve standard of living & 12 & 30 & 3 & 5 & 0 \\
It helps to build a house & 10 & 36 & 20 & 30 & 4 \\
It helps to ease burden & 5 & 18 & 10 & 15 & 2 \\
Income increased after receiving zakat & 8 & 36 & 1 & 5 & 0 \\
Life became easier & 9 & 38 & 1 & 2 & 0 \\
It helps to pay medical expenses & 9 & 14 & 11 & 16 & 0 \\
\hline
\end{tabular}

Note. $\mathrm{SA}=$ Strongly agree, $\mathrm{A}=\mathrm{Agree}, \mathrm{NT}=$ Not decided, $\mathrm{DA}=$ Disagree, and SDA=Strongly disagree.

\section{Analysis of Zakat Collection and Distribution}

As shown in Table 6, the number of zakat payers of wealth increased drastically in 2002 to 3,454 persons compared to 2001, when only 956 
persons paid. The number decreased gradually in 2003 and 2004. However, in 2005, there was a drastic increase due to the participation of the depositors of the Islamic financial institutions in the country, Taib Amanah Fund (TAIB) and Bank Islam Brunei Darussalam (BIBD). The changes in the administrative structure caused the zakat payment for 2006 and 2007 to be postponed until 2008 both for the banks' zakat and the depositors' zakat, resulting in a sharp drop in the number of payers and the amount collected. The decrease in zakat collection also has a connection to the economic downturn, which has affected the profits of businesses. The lower the businesses' profit is, the less zakat will be paid to zakat collectors.

Table 6

Total Amount of Zakat and Number of Payers

\begin{tabular}{lccc}
\hline Year & $\begin{array}{c}\text { Total collection } \\
\text { (BND\$) }\end{array}$ & Number of payers & $\begin{array}{c}\text { Payment per Payer } \\
\text { (BND\$) }\end{array}$ \\
\hline 2001 & $9,849,351$ & 956 & 10,302 \\
2002 & $13,804,900$ & 3,454 & 3,997 \\
2003 & $10,869,270$ & 3,454 & 3,147 \\
2004 & $11,173,064$ & 4,112 & 2,717 \\
2005 & $14,751,913$ & 4,569 & 3,229 \\
2006 & $11,096,859$ & 4,667 & 2,378 \\
2007 & $11,292,007$ & 5,004 & 2,257 \\
2008 & $11,820,873$ & 5,160 & 2,291 \\
2009 & $19,918,345$ & 4,122 & 4,832 \\
\hline
\end{tabular}

Source. Islamic Religious Council of Brunei (2010).

On the other hand, for zakat payers on Zakat Fitrah, there is no problem. Since people are aware of the importance of paying Zakat Fitrah, a majority of zakat payers will pay Zakat Fitrah during the fasting month (Ramadan). As shown in Table 7, the number of zakat Fitrah payers increased gradually from 2001 to 2009.

Table 7

Total Amount of Zakat Fitrah, 2001-2009

\begin{tabular}{ccc}
\hline Year & Total collection (BND\$) & Number of payers \\
\hline 2001 & 692,011 & 251,421 \\
2002 & 789,453 & 255,855 \\
\hline & & (continued)
\end{tabular}


IJMS 19 (2), 75-102 (2012)

\begin{tabular}{ccc}
\hline Year & Total collection (BND\$) & Number of payers \\
\hline 2003 & $1,407,145^{*}$ & 260,205 \\
2004 & 765,400 & 276,116 \\
2005 & 780,790 & 281,504 \\
2006 & 805,575 & 289,929 \\
2007 & 813,170 & 292,374 \\
2008 & 831,531 & 299,003 \\
2009 & 843,137 & 302,981 \\
\hline
\end{tabular}

Note.* The amount doubled due to zakat collection of two fasting months happened in this year.

Source. Islamic Religious Council of Brunei (2010).

\section{Eligible Categories to Receive Zakat Funds in Brunei}

There are six Asnaf or categories of people who are eligible to receive zakat funds in Brunei Darussalam ${ }^{3}$. These categories are as follows:

(1) The poor: The poor are unable to earn a living, their source of income is from non-Halal activities, they do not have wealth, or they have some but it is not enough, and they do not have an income or not enough to support their dependents (Rahman, 2003).

(2) The needy: The needy are those who have only a little income or wealth that can cover only half or more but not all of the family members' basic needs. They also include those who are able to work and their sources of income are not from permissible or Halal activities, or they have wealth and income, but it is not enough to support their dependent (Rani, 2008).

(3) Amil: The Amil are those who are appointed to collect zakat on behalf of MUIB.

(4) Muallaf: The Mualaf are people who have converted to Islam. MUIB has defined three criteria for those who are eligible to receive zakat fund under this category as follows: first, the receiver should have converted to Islam within the previous 10 years and not performed Hajj. Second, a new applicant who wants to convert to Islam should be justified first by a Shari'ah lawyer, and the applicant must join an introductory course on Islam organized by an authorized body. Third, new converts who want to perform Hajj must have fulfilled all the requirements, not performed Hajj, and passed an interview (Pusat Da'wah Islamiah, 1999; Baki, 2007). 
(5) Gharimin: The Gharimin group is normally those who have gone into debt on building projects for the public such as the construction of mosques or schools, and recently, MUIB has considered including those who are in debt for basic necessities such as the purchase of government houses.

(6) Ibn al-Sabil: These are people who are travelling for purposes that are not against Shari'ah and in need of help due to not having enough money available at a given time.

\section{The Process of Applying for Zakat}

First, to apply for zakat, the applicants must first get a form from the Section of Zakat Collection and Distribution. Then, after the applicants fill out the form, they must present the form to the head of the village to get it stamped. The head of the village will write a statement to verify whether or not the applicants are eligible for zakat funds. After that, the recipients will give the forms to the Section of Zakat Collection and Distribution. Next, an application/investigation/observation unit will gather and organize the forms into three categories: new, renewal, and appeal applications. After that, the staff will investigate the applicants to see whether they are really eligible to receive zakat funds or not. After the investigation, the staff will write a report about the applicants they have visited. Next, the staff will type the reports nicely and present them to the Ahli Jawatankuasa Meneliti (Committee of Analyzing). If this committee confirms that the applicants are eligible, they will send the forms and the reports to Jawatankuasa Mengeluarkan Zakat (Committee of Zakat Distribution) for meetings and confirmation. According to MUIB practices, one case will take about 40 days. However, sometimes, due to a lack of evidence and information in a report, the Ahli Jawatankuasa Meneliti (Committee of Investigation) will have to ask the staff to go for a second visit, which will cause a case to take about three months to complete (Abdullah, 2010b).

Before 2009, all applications were handled case by case. Each case was put into a file for further action. As a result, the management in previous years was quite slow and inefficient. However, after 2009, the management changed the way they handled cases. They put the cases into different groups as shown in Tables 10,11, 12 and 13. The groups are allocated by timeframe. These groups are divided into two categories: Fakir and Miskin. The funds to be distributed vary between 
these two groups. There were four groups from October 2009 to September 2010.

\section{Distinction between Fakir and Miskin}

In Brunei, the average monthly expenses per person total BND\$253. Thus, referring to MUIB guidelines, the total monthly expenses for Bruneian family, on average, is BND\$1518. In this case, the father's (head of family) designated monthly income is BND $\$ 1,000$. However, if the head of a family's monthly income is just BND $\$ 400$, this family would fall under the needy group because his wealth can cover only $50 \%$ or less than half of the designated family head's monthly income. If the family falls into the Fakir category, the head of the family will receive $B N D \$ 10,000$, and the dependents will receive $B N D \$ 5,000$ each. If the family is considered poor (Miskin), this Asnaf would be put in category B, Miskin; the head of the family would receive BND $\$ 2,000$ and the dependents would receive BND \$5,000 each (Islamic Religious Council of Brunei, 2010; Abdullah, 2010b) ${ }^{4}$.

Table 8

Number of Zakat Recipients in the Fakir and Miskin Categories, 2001-2009

\begin{tabular}{lccccccccc}
\hline Year & 2001 & 2002 & 2003 & 2004 & 2005 & 2006 & 2007 & 2008 & 2009 \\
\hline Total & 3,543 & 3,631 & 3,347 & 13,298 & 19,420 & 16,751 & 16,210 & 16,450 & 16,378 \\
Change (\%) & & 2.5 & -7.8 & 297.3 & 46.0 & -13.7 & -3.2 & 1.5 & -0.4 \\
\hline
\end{tabular}

Source. Islamic Religious Council of Brunei (2010).

Table 8 shows the number of zakat recipients in the Fakir and Miskin categories from 2001 to 2009. The number in these categories increased drastically from 3,543 persons in 2001 to 13,298 persons in 2004. The increase of almost 12,000 persons was due to some adjustments in the government policy for distributing the zakat funds. That is, the head of the family and all dependents were counted as eligible to receive zakat. In the previous years, the zakat for Fakir and Miskin was given only to the head of the family.

In 2009 , there was a $0.4 \%$ decrease in the number of recipients of Fakir and Miskin compared to the previous year (Table 8). However, 
the share of Zakat Fakir and Miskin increased tremendously from $67.9 \%$ (2008) to $93.4 \%$ (2009) (Table 9). This shows that the amount of zakat increased is clearly not due to the number of zakat recipients.

According to MUIB guidelines before 2009, the amount distributed to Fakir and Miskin was as follows: Miskin families received amounts of BND $\$ 200$ for the head of the family, BND $\$ 100$ for the wife, BND $\$ 65$ per family member for food, and BND $\$ 60$ per person for the children's school expenses. For Fakir, the head of family received BND $\$ 1,300$ and the dependent family members BND $\$ 380$ each. In 2009, there were changes in the distribution of zakat to the Asnaf Fakir and Miskin as agreed to by the Committee of Zakat Distribution during the $7^{\text {th }}$ Islamic Religious Council meeting held on $25^{\text {th }}$ August 2009. Due to the limited amount of money in the pool of zakat funds, the zakat distribution committees held another meeting on $18^{\text {th }}$ February 2010 about the new zakat distribution.

\section{Table 9}

Share of Zakat Recipient by Category (\%)

\begin{tabular}{ccccccc}
\hline Year & Amil & Fakir $\mathcal{E}$ Miskin & Muallaf & Ibn al-Sabil & Gharimin & Total \\
\hline 2001 & 5.2 & 67.9 & 25.1 & 0.0 & 1.8 & 100.0 \\
2009 & 0.1 & 93.4 & 2.9 & 0.0 & 3.6 & 100.0 \\
\hline
\end{tabular}

Source. Islamic Religious Council of Brunei (2010).

Table 10

Zakat Distribution to Recipients of Fakir and Miskin for Group 1

\begin{tabular}{|c|c|c|c|}
\hline $\begin{array}{c}\text { Group } 1 \\
\text { (Fakir) }\end{array}$ & & $\begin{array}{l}\text { Group } 1 \\
\text { (Miskin) }\end{array}$ & \\
\hline $\begin{array}{l}\text { Oct. } 2009 \text {-Sep. } \\
2014 \\
\text { (5 years) }\end{array}$ & $\begin{array}{l}\text { Head of family will } \\
\text { receive BND } \$ 20,000 \text {; } \\
\text { dependents will receive } \\
\text { BND } \$ 10,000 \text { each for a } \\
\text { period of } 5 \text { years or } 60 \\
\text { months. }\end{array}$ & $\begin{array}{l}\text { Oct. } 2009 \text {-Sep. } \\
2010 \\
\text { (1 year) }\end{array}$ & $\begin{array}{l}\text { Head of family will } \\
\text { receive BND } \$ 3,000 \text {; } \\
\text { dependents will } \\
\text { receive BND } \$ 2,000 \\
\text { each for a period of } 1 \\
\text { year (12 months). }\end{array}$ \\
\hline
\end{tabular}

Source: Islamic Religious Council of Brunei (2010). 
IJMS 19 (2), 75-102 (2012)

\section{Table 11}

Zakat Distribution to Recipients of Fakir and Miskin for Group 2

\begin{tabular}{|c|c|c|c|}
\hline $\begin{array}{c}\text { Group } 2 \\
(\text { Fakir })\end{array}$ & & $\begin{array}{l}\text { Group } 2 \\
\text { (Miskin) }\end{array}$ & \\
\hline $\begin{array}{l}\text { May } 2010 \text {-April } \\
2015 \\
\text { (5years) }\end{array}$ & $\begin{array}{l}\text { Head of family will } \\
\text { receive BND } \$ 20,000 \text {; } \\
\text { dependents will receive } \\
\text { BND } \$ 10,000 \text { each for a } \\
\text { period of } 5 \text { years or } 60 \\
\text { months. }\end{array}$ & $\begin{array}{l}\text { May } 2010 \text { - } \\
\text { April } 2011 \\
\text { (1 year) }\end{array}$ & $\begin{array}{l}\text { Head of family will } \\
\text { receive BND } \$ 3,000 \text {; } \\
\text { dependents will } \\
\text { receive BND } \$ 2,000 \\
\text { each for a period of } 1 \\
\text { year (12 months). }\end{array}$ \\
\hline
\end{tabular}

Source. Brunei Islamic Religious Council (2010).

Table 12

Zakat Distribution to Recipients of Fakir and Miskin for Group 3

\begin{tabular}{|c|c|c|c|}
\hline $\begin{array}{c}\text { Group } 3 \\
\text { (Fakir) }\end{array}$ & & $\begin{array}{l}\text { Group } 3 \\
(\text { Miskin })\end{array}$ & \\
\hline $\begin{array}{l}\text { May } 2010 \text {-Oct. } \\
2012 \\
(2.5 \text { years })\end{array}$ & $\begin{array}{l}\text { Head of family will receive } \\
\text { BND } \$ 10,000 \text {; dependents } \\
\text { will receive } B N D \$ 5,000 \\
\text { each for a period of } 2.5 \\
\text { years ( } 30 \text { months). }\end{array}$ & $\begin{array}{l}\text { May } 2010- \\
\text { April } 2011 \\
(1 \text { year })\end{array}$ & $\begin{array}{l}\text { Head of family will } \\
\text { receive BND } \$ 2,000 \text {; } \\
\text { dependents will } \\
\text { receive BND } \$ 1,200 \\
\text { each for a period of } \\
1 \text { year (12 months). }\end{array}$ \\
\hline
\end{tabular}

Source. Islamic Religious Council of Brunei (2010).

Table 13

Zakat Distribution to Recipients of Fakir and Miskin for Group 4

\begin{tabular}{|c|c|c|c|}
\hline $\begin{array}{c}\text { Group } 4 \\
\text { (Fakir) }\end{array}$ & & $\begin{array}{l}\text { Group } 4 \\
\text { (Miskin) }\end{array}$ & \\
\hline $\begin{array}{l}\text { Sep. } 2010 \text { - } \\
\text { Feb. } 2013 \\
\text { (2.5 years) }\end{array}$ & $\begin{array}{l}\text { Head of family will receive } \\
\text { BND } \$ 10,000 \text {; dependents } \\
\text { will receive BND } \$ 5,000 \\
\text { each for a period of } 2.5 \\
\text { years ( } 30 \text { months). }\end{array}$ & $\begin{array}{l}\text { May } 2010- \\
\text { Aug. } 2011 \\
\text { (1 year) }\end{array}$ & $\begin{array}{l}\text { Head of family will receive } \\
\text { BND } \$ 2,000 \text {; dependents } \\
\text { will receive BND } \$ 1,200 \text { each } \\
\text { for a period of } 1 \text { year (12 } \\
\text { months). }\end{array}$ \\
\hline
\end{tabular}

Source. Islamic Religious Council of Brunei, 2010). 


\section{Difficulties and Problems}

The present investigation identified some difficulties and problems faced by the Department of Zakat Collection and Distribution (DZCD) that involve the process of receiving the applications, investigating the applicants, and making the necessary recommendations for submission to the higher committee for their approval and subsequent disbursement of the zakat funds. The problems are:

(1) The difficulties in processing the applications, as the staff members of DZCD are multi-tasking, doing several jobs at a time.

(2) A huge number of applications, which has resulted in the accumulation of more than 1,000 applications since 2006.

(3) DZCD officers are not assigned to specific areas, causing a lack of a sense of responsibility among the staff to make sure that their clients are progressing.

In February 2009, a new initiative was introduced to speed up the application process. The tasks given to the staff members were reduced so that they can be more focused. However, the same procedures still applied. The chief officer of DZCD said that, although they were speeding up the process, the number of new applications received was higher than the actual number of applicants being visited by MUIB officers.

Moreover, MUIB is now fully equipped with a computerized zakat collection system. The system will allow direct communication between Amil (including banks) and MUIB's district offices with the main office. Using only the applicants' identity card number, the staff can find the information in the system. The use of the computerized zakat collection system will enable the involvement of a wider range of the community and is expected to be more secure and to provide an improved monitoring mechanism. It was very important to speed up the processing time and to organize the many application forms into three categories: new, renewal, and appeal. In addition, this has made them more efficient now in terms of the distribution and receipt of zakat applications.

The accumulated zakat funds are saved in the Islamic Bank of Brunei Darussalam. From 1956 until December 2007, the accumulated zakat funds in the bank totaled about \$262 million. His Majesty the Sultan of Brunei Darussalam raised concern over the state of zakat affairs in the country during the MUIB annual meeting in January 2009. He 
referred to the 2004 amount of accumulated zakat funds, which stood at BND\$240 million (Brunei Times, January 2009). In response to this, MUIB took the step of disbursing about BND $\$ 100$ million of the zakat funds by distributing it to more than 4,000 recipients in October 2009 and declaring them free from poverty (Azaraimy, 2009).

The Empowerment Zakat Recipients Program (EZRP) was launched on 5th November 2007. The program is a joint effort by the Islamic Religious Council of the Ministry of Religious Affairs and the Youth Development Centre. The objective of the program is to provide training for the poor and needy to get skills and have the opportunity to get jobs at government offices or start their own businesses. They will be assisted to start a business and to get capital from the zakat funds. Divided into two sessions, the participants attend class-based lessons for three months before undergoing practical training at government departments and companies (Islamic Religious Council of Brunei, 2010).

The participants should be from the poor and needy Asnaf groups and must be willing to develop and improve their standard of living. The training is a three-month program plus six months of work attachment. The participants are offered skills in using computers and office administration, baking cakes and pastries, cooking and catering, salon and hairdressing, car repair and welding, and basic sewing and embroidery. The facilities provided are transportation, an allowance for stationery, uniforms, training equipment, a refreshment allowance, and a pocket money allowance. About BND $\$ 2$ million has been allocated for this program to cover a five-year period from 2008 through 2012 (Islamic Religious Council of Brunei, 2010).

The responses from the participants were not encouraging, as only 18 participants registered out of 102 candidates who were approached to join the program. Itisimportanttonotethat this programisseparatefrom the capital assistance scheme handled by MUIB (Abdullah, 2010a).

Based on this discussion, the objectives of the zakat institution in Brunei can be reorganized and restructured as follows:

(1) In addition to the collection and disbursement of zakat, the zakat institution intends to formulate a database of zakat rituals and to reinforce the spirit of cooperation among the zakat payers and recipients;

(2) The government has to carry out the function of the collection of zakat from both individuals and firms; 
(3) The recruiting of qualified zakat collectors should involve a training program in technical and legal skills;

(4) Financial and technical assistance should be provided in terms of productive family projects and production means to uplift the poor; and

(5) Information should be provided and research conducted for the establishment of a database.

The collection and disbursement of zakat from payers to its entitled Asnaf is carried out throughout the year. The disbursement process of zakat to its entitled beneficiaries is based entirely upon the function of collecting zakat itself. However, this situation entails the restructuring of the zakat institution as an Islamic entity to pursue the eradication of poverty and realize equity and social solidarity. The main function of the zakat institution is to distribute zakat to the entitled groups mentioned in the Qur'an in terms of money or productive activities. The philosophy behind providing productive projects is to enhance work habits as encouraged by Islam, which, in turn, reduces the number of recipients and eventually increases the number of zakat payers.

\section{Policy Implications}

Zakat administration in Brunei is naturally facing some problems in terms of the assessment and collection of zakat. Some policy implications can be presented as follows:

(1) In regard to Brunei law, the penalty for not paying zakat has not been enforced. The possible reasons are as follows:

(a) There is no proper database of zakat payers, so it is impossible for the MUIB to track Muslims who fail to pay zakat.

(b) The zakat office is small and able to carry out only daily administrative duties.

(c) The zakat administration is not authorized to carry out investigations, such as checking the accounts and confidential financial details of zakat payers.

(d) Consequently, the only thing that the officers can do given that no law has been enforced against those who have refused to pay zakat is by generating more awareness among the general public regarding their responsibility as members of the Islamic community to pay their zakat. 
(2) Some Muslims, instead of paying zakat to MUIB, would rather pay zakat through unofficial or informal channels. A number of possible factors may be involved in this practice:

(a) Payers prefer to pay zakat to their close relatives or neighbors who are known to be eligible to receive zakat funds.

(b) There is a lack of publicity and information on the types of zakat that should be paid.

(c) Payers have a negative perception of the zakat administration's management of zakat funds. They believe that the zakat administration does not efficiently distribute the zakat funds. To overcome these problems, the zakat administration should educate people and allow other parties to be involved such as universities and the media.

(3) Modern sources of income should be covered and subjected to zakat effectively. To enhance efficiency and reliability in the calculation and distribution of zakat funds, a proper mechanism has to be adopted. Also, such measures have to be implemented to ensure that all those who are eligible to pay zakat are willing to pay and doing so accurately and that the funds reach those who truly deserve it.

(4) There is room for improvement in terms of zakat administration and organization in Brunei. The computerized system has yet to be stabilized so that the use of the database will be more efficient and reliable. Much data is yet to be entered into the system.

\section{Conclusion}

Zakat is an important institution in the economic system of Islam, which is one of the five pillars on which the Islamic code of life is founded. Zakat is an obligation of Muslims to give a specific amount of their wealth according to certain conditions and requirements to specific categories of beneficiaries mentioned in Islamic sources. The concept of zakat in Islam reflects a strong concern with social justice and well-being (Kahf, 1997).

Zakat practice in Brunei varies from that of other Muslim countries in terms of coverage, distribution, and method of collection. In coverage, 
the zakat administration should cover all types of Zakat al-Mal, which includes all kinds of zakatable wealth including tradable items and financial and monetary assets (Abdullah, 2010b). The institution of zakat in Brunei should have some positive economic implications. Therefore, it is considered an obligatory poverty eradication program that provides a compulsory social security system in society.

The findings prove that zakat management in Brunei is progressing to achieve the objectives of zakat system: providing social security for the poor and the needy in society, developing balanced economic growth, and committing an act of spiritual purity and development. A majority of the zakat recipients' lives become easier in terms of better living and better education, and the most important thing is that they can acquire their basic necessities including food, shelter, clothes, medicine, and education, which are meant to maintain life and, hence, fulfill the objective of zakat as a whole.

Contemporary zakat administration in Brunei must move forward to confirm that the compulsory implementation of zakat through rules and laws is effective and efficient in reducing inequality in the distribution of income and wealth. Besides its basic religious value, zakat has a social aspect that aims at freeing the community from the blight of poverty. It also has an economic aspect that is aimed to drive the collected funds into circulation. This, in turn, helps to relieve the community of most of its charitable burdens. By its very nature and purpose, the institution of zakat is the most powerful means of translating the Islamic principle of human brotherhood into a living reality. It is for this very reason that the institution of zakat lays special stress on rehabilitation, on promptly restoring the impoverished individual to a condition of self-sufficiency, thereby enabling him to once more take his place as a productive member of the social group, actively contributing to its prosperity.

This paper outlines the findings from the interview with the officers and from analyzing and examining the questionnaires. The findings from both the interview and questionnaires have answered the research questions about the zakat administration in Brunei Darussalam; collection and distribution; and zakat recipients' perception of zakat in their lives.

Based on the analysis findings; the present paper can conclude and identify the following regarding the zakat distribution in Brunei Darussalam: 
IJMS 19 (2), 75-102 (2012)

(1) The Unit of Zakat Collection and Distribution gives priority to zakat distribution to the Asnaf Fakir and Miskin

(2) There was a decrease in the amount for Amil in 2006 to 2009. It is questionable why this happened since this Amil deserves to get the same share of zakat as the other Asnaf.

(3) The Empowerment Zakat Recipients Program (EZRP) aims to provide training for the poor and needy to get skills and have the opportunity to get jobs. The response from the participants was not encouraging, as only 18 participants registered out of the 102 candidates who were approached to join this programme. It is important to observe that this program is handled separately from the capital assistance scheme. In addition, only three respondents said that they had joined the programme. It is a clear indication that there is a lack of awareness among the public about this program.

Future research should use a large sample to enhance the validity of the current findings. Using a different approach may contribute to better understanding of the management of zakat funds and improving the contemporary practices of zakat institution.

\section{End Notes}

See the Laws of Brunei, 1/1984, Religious Council and Kadi Courts, Chapter 77, Section 114. US\$1.00 =BND\$1.22 (as of $1^{\text {st }}$ October 2012).

There are another two categories; Riqab: To free slaves and those who are oppressed and Fi Sabilillah: Fighters in the cause of Allah (SWT). As stated by the Mufti's fatwa (reference number: 14 MKB 3/1969, dated on 1st September 1970), these two categories do not exist in Brunei Darussalam. Nevertheless, a special committee has been formed under the Ministry of Islamic Religious Affairs in 2005 to review the position of the two categories.

$4 \quad$ There is no extreme poverty in Brunei, but to some extent the problem is with relative poverty. Some services such as primary health care and education are provided free by the government. Welfare support is also given to several types of citizens. 


\section{References}

Abdullah, R. (2010a). Zakat fund as source of capital for poor and needy in Brunei Darussalam. The $1^{\text {st }}$ International Conference on Islamic Finance (ICIF 2010). $1^{\text {st }}-2^{\text {nd }}$ March 2010. Rizqun Hotel, Bandar Seri Begawan, Brunei Darussalam: UNISSA.

Abdullah, R. (2010b). Zakat management in Brunei Darussalam: A case study. The $7^{\text {th }}$ International Conference- The Tawhidi Epistemology: Zakat and Waqaf Economy. 6-7 January 2010. Bangi, Selangor, Malaysia: Institute of Islam Hadhari, UKM.

Abioye, M. O. (2008). Accountability for zakat disbursement: An exploratory study of empowerment schemes in zakat institutions (Unpublished doctoral dissertation). International Islamic University Malaysia, Bangi, Malaysia.

al-Hashimi, M. A. (2007). The ideal Muslim society as defined in the Qur'an and Sunnah. Jeddah, Saudi Arabia: International Islamic Publishing House.

Al-Qaradawi, Y. (1997). Figh az-zakah (24th ed.). Beirut, Lebanon: $\mathrm{Mu}$ 'assasat al-Risalah.

Awad, M. H. (1998). Poverty eradication in Islamic and other economic systems. Khartoum, Sudan: UNDP.

Azaraimy, H. H. (2009). Sultan queries zakat distribution's balance. Borneo Bulletin. Retrieved from: http://www.bruneionline.com

Bakar, M. A., \& Ghani, A. A. (2011). Towards achieving the quality of life in the management of zakat distribution to the rightful recipients (The poor and needy). International Journal of Business and Social Science, 2(4), 237-245.

Baki, H. M. (2007). Panduan mengira zakat. Negara Brunei Darussalam: Pusat Da'wah Islamiah Publisher, Kementerian Hal Ehwal Ugama.

Billah, M. M. (2007). Applied Islamic law of trade and finance: A selection of contemporary issues. Selangor, Malaysia: Sweet \& Maxwell Asia Publisher.

Chapra, M. U. (1992). Islam and the economic challenge. Leicester, UK: The Islamic Foundation.

Chaudhry, M. S. (1999). Fundamentals of Islamic economic system. Lahore, Pakistan: Burhan Education and Welfare Trust.

Hassan, M. K. (2010). An integrated poverty alleviation model combining zakat, awqaf and micro-finance. The 7 th International Conference - The Tawhidi Epistemology: Zakat and Waqaf Economy. Bang, Malaysia: UKM Press. Retrieved from http://www.ukm. my/hadhari/sites/default/files/prosiding/p14.pdf 
Islamic Religious Council of Brunei. (2010). Pengelolaan zakat di Negara Brunei Darussalam. Negara Brunei Darussalam: Islamic Religious Council of Brunei, Kementerian Hal Ehwal Ugama.

Kahf, M. (1990). Figh of zakah: The principle of socio-economic justice in the contemporary. Jeddah, Saudi Arabia: Islamic Research and Training Institute, IBD.

Kahf, M. (Ed.). (1997). Economics of Zakah: Book of reading. Jeddah, Saudi Arabia: Islamic Research and Training Institute, IBD.

Oxford Business Group. (2011). Brunei Darussalam Report 2011. London, UK: Oxford Business Group.

Pusat Da'wah Islamiah. (1999). Zakat: Meningkatkan kesentosaan dan perpaduan Masyarakat Negara Brunei Darussalam: Bandar Seri Begawan, Brunei Darussalam: Pusat Da'wah Islamiah Publisher, Kementerian Hal Ehwal Ugama.

Rahman, M. (2003). Zakat collection primarily based on figh uz zakat. Leicester, UK: The Islamic Foundation.

Rani, A. N. (2008). Isu-isu ekonomi: Teori analisis dari perspective ekonomi Islam. Negara Brunei Darussalam: Dewan Bahasa dan Pustaka.

Sadeq, A. A. (1994). A survey of the institution of zakah: Issues, theories and administration. Jeddah, Saudi Arabia: Islamic Development Bank and Islamic Research and Training Institute, IRTI.

Sahl, I. M. (1997). Poverty from an Islamic perspective. Seminar on Poverty: Towards an Agenda for Research. Kuala Lumpur, Malaysia: UIAM Press.

Zayas, F. G. (2003). The law and institution of zakat. A. Z. Abbasi (Ed.). Kuala Lumpur, Malaysia: The Other Press. 